The Geneva Papers on Risk and Insurance, 17 (No. 64, July 1992), 406-414

\title{
Sea-Level Changes and Forecasting Floodrisks
}

\author{
by M. J. Tooley*
}

\section{Introduction}

One of the conclusions reached in the 1990 UNEP report on The State of the Marine Environment was that,

"Half the world's population dwells in coastal regions which are already under great demographic pressure, and exposed to pollution, flooding, land subsidence and compaction and to the effects of upland water diversion. A rise in sea level would have its most severe effects in low-lying coastal regions, beaches and wetlands. In developed countries protection for some regions will be possible, whereas in developing countries without adequate technical and capital resources it may not be. The frequency and severity of flooding would increase, and coastal structures and port facilities would require reinforcement."

Several points emerge from this conclusion. In the first place, large coastal-dwelling populations are already at risk as the result of in-migration, permitted development, and land-use changes. In the second place, the risk has been increased as the result of maninduced changes such as drainage and water extractions affecting the relationship of land levels to sea levels. In the third place, a rise in sea level, caused by the enhanced greenhouse effect, will have a universal effect, impacting at different intensities on more than half the world's population, their agriculture, infrastructure and industry. In the fourth place, the frequency and severity of flooding from aperiodic events, such as storm surges, hurricanes and cyclones, would increase.

Bird (1985) has noted that $70 \%$ of the sandy shorelines of the world are at present recording net erosion, loss of sediment and shoreline retreat. Localised flooding during storms is associated with this erosion. In Rio de Janeiro city all the barrier beaches, such as Ipanema, Copacabana and Leblon, have been developed for residential, commercial and tourist purposes and all are subject to flooding. In Bombay, high-rise apartments have been built south of the city on marshland and are flooded during the monsoon each year: north of Bombay at Versova Beach, whilst the foundations of Parsee houses are being eroded and destroyed by the sea, new high-rise apartments are being built on adjacent sites. On the

* Environmental Research Centre, University of Durham, Durham, DH1 3LE. Paper presented at the Fourth International Geneva Association Conference in London, on October 29, 1991. 
Portuguese coast at Ofir the foundations of holiday apartments are being actively eroded, and all along the eastern seaboard of the United States of America, real estate is being damaged by shoreline erosion and retreat. Along the European coasts, similar examples can be found (Tooley \& Jelgersma 1992).

Attention has been drawn to the concentration of population, industry and energy resources in the coastal lowlands of north-west Europe (Tooley \& Jelgersma 1992). There are about 123 nuclear reactor sites on or close to the world's coasts, of which about 51 are in Europe (Varley 1991).

In the United Kingdom alone all but one of the reactor sites are on the coast and several are at low altitude in subsiding areas, and on unstable, ephemeral geomorphological features. The capital expenditure on the UK nuclear stations up to 1977 exceeded £ 1 billion (Tooley 1979).

At Dungeness, in Kent on the Channel coast of England, the integrity of the site is maintained by beach nourishment with flinty shingle. Further west, agricultural land and tourist developments are protected by a sea wall, which has been further protected by beach nourishment to the extent of $150,000 \mathrm{~m}^{2}$ initially and annual recharge of $20,000 \mathrm{~m}^{2}$. (Robinson \& Stone 1990). Recharge will be required indefinitely if the integrity of sites is to be maintained and land protected from flooding.

Industrial development has tended to concentrate on reclaimed land at low altitude near the coast where port facilities are available. In Europe, until the early 1980's this type of concentrated development with high levels of capital expenditure occurred in scheduled areas identified as Maritime Industrial Development Areas (MIDAS) of which Rotterdam-Europort is the most successful example. They have been protected by sea embankments and sea locks, and, in the case of part of the densely-populated and heavilyindustrialised Thames coastal lowlands by the Thames Barrage.

All these coastal areas, their resident populations and investments are at risk from aperiodic storm surges, hurricanes and typhoons and from periodic sea-level rise, amplified by the enhanced greenhouse effect.

\section{Present-day land / sea-level relationships}

Extreme water levels occur periodically and aperiodically along the world's coastlines. The former can be predicted and include high spring tides and high astronomical tides. The latter cannot be predicted with any certainty, and include storm surges, hurricanes, cyclones and tsunamis.

Storm surges are meteorologically-forced events generating extreme water levels that can, by themselves, produce devastating effects on coastlines. The infamous 1953 storm surge in the North Sea raised water levels by up to $3 \mathrm{~m}$ above predicted tidal levels, and the consequential overtopping and breaching of embankments led to the loss of over 2100 lives in the United Kingdom and the Netherlands. In the United Kingdom, 24000 houses were flooded, 200 major industrial premises were inundated and were put out of production for several weeks, 12 gas works and 2 electricity generating stations were damaged and supplies of gas and electricity were disrupted. Water supplies were contaminated and sewage disposal was disrupted. Transport was badly affected: 11 A-roads were impassable and 200 miles of railway were put out of action. Some 160,000 acres of agricultural land were flooded by sea water and no crops of any value were grown in 1953 (Spalding 1954). 
The 1953 storm surge affected the Dutch, German and Danish coasts, and in the past 35 years there has not been an event that has wrought such damage over such an extensive area.

There have been during this period events of limited extent. The 1977 storm surge in the Irish Sea added $2.5 \mathrm{~m}$ to predicted levels, and at Preston extreme water levels rose to $+7.5 \mathrm{~m}$ (O.D. = Ordnance Datum = mean sea level at Newlyn). On the south shore of Morecambe Bay, the sea embankment was overstopped and breached, and 7100 acres of farmland were inundated or waterlogged up to an altitude of $+5.5 \mathrm{~m} \mathrm{O}$. D. In February 1990, a storm surge affected the Clwyd coastal lowlands in North Wales, the sea wall was demolished and the lowlands flooded to depths of 1.2 to $1.8 \mathrm{~m}$ for up to 5 days some $2 \mathrm{~km}$ inland of the present coast and up to an altitude of $+5.4 \mathrm{~m} \mathrm{O}$.D. Some 2800 properties were flooded and 5000 people were evacuated. Repair of flooddamaged property took 12-20 weeks, and estimates of the cost of repairs to the housing stock alone ranged from $£ 22.4 \mathrm{~m}$ to $£ 100.8 \mathrm{~m}$.

In Germany in 1962 a storm surge in the North Sea resulted in extensive inundation of Hamburg, $16 \%$ of the city was flooded, 300 people died and damage to property amounted to DM 100 million. Between 1962 and 1989, some DM 1700 million have been expended to improve the sea defences and raise the sea embankments to $+9 \mathrm{~m}$ mean sea level. These embankments protect 180,000 residents, and 140,000 employees in Hamburg live and work at risk in an area that is subsiding, and high tide levels annually increase. The value of property in Hamburg is likely to be affected by sea flooding amounts to DM 16,000 million.

The scale of damage associated with storm surges in the U.K. and elsewhere in Europe is several orders less than loss of life and damage to property in countries affected by cyclones, hurricanes and typhoons. In the Indian Ocean, the Bay of Bengal is notorious for the meteorologically-induced storm surges that affect the coasts of India, Bangladesh and Burma. In 1970, winds of $60 \mathrm{~m} \mathrm{sec}^{-1}$ resulted in extreme water levels $9 \mathrm{~m}$ higher than predicted levels along the coast of the Ganges delta. The extensive flooding that occurred led to the death of more than 200,000 people, and the event became known as the deadliest tropical cyclone in history.

The extent and intensity of impact of extreme water levels on coastal lowlands depends not only on the quality of both natural and man-made sea defences, but also on the topography of the coastal lowlands protected by these defences.

Ground altitudes in the world's lowlands are affected by natural processes such as sedimentation and subsidence, and by man-induced changes such as water and gas extraction, drainage, oxidation of organic material and consolidation which lead to reductions in ground altitudes. In an area in the western Fenland in the United Kingdom, ground altitudes have fallen from +1.6 to $-2.3 \mathrm{~m} \mathrm{O}$. D. in 130 years: the average rate of lowering was $30 \mathrm{~mm} \mathrm{yr}^{-1}$ with accelerated rates of $220 \mathrm{~mm} \mathrm{yr}^{-1}$ in the first 5 years following drainage. Without natural and artificial sea defences around the Wash, at each present high tide, the sea would penetrate $45 \mathrm{~km}$ across the Fenlands, and the water would stand $6 \mathrm{~m}$ deep. In the Netherlands, the penetration of sea water at high tide would be $90 \mathrm{~km}$, and in the Zhujiang delta (Pearl River delta), where $81 \%$ lies below $+0.9 \mathrm{~m}$ Yellow Sea Datum, earth embankments prevent the sea penetrating $70 \mathrm{~km}$ beyond Canton. 
The conclusion that can be drawn is that the present day land-/sea-level relationships of the world's coastal lowlands indicate an existing vulnerability to long period marine inundation. Measurements of ground altitudes in coastal lowlands indicate declining altitudes, exacerbating the extent and intensity of risk. It is not necessary to wait for the consequences of the enhanced greenhouse effect, coastal lowlands are already at risk given present day land-/sea-level relationships.

\section{Long term sea-level changes}

The coastal lowlands and continental shelves of the world are an archive of sea-level and coastline changes. The archive comprises alternating inorganic and organic sediments, the former laid down under marine conditions, and the latter under brackish or freshwater conditions or under terrestrial conditions. Analyses of the plant and animal remains from these sediments elucidate the succession of environmental changes and radiocarbon dating provides a chronological framework.

Sea-level rises and falls during an interglacial-glacial cycle with an amplitude for the last 18,000 years of $c .120 \mathrm{~m}$. The average rate of sea-level rise over the past 18,000 years was $c .6 \mathrm{~mm} \mathrm{yr}^{-1}$ and over the past 10,000 years $2 \mathrm{~mm} \mathrm{yr}^{-1}$, but there were periods of enhanced rise associated with the catastrophic discharge of melt water from beneath ice sheets during deglaciation. For example, 12,000 and 9,000 years ago, meltwater discharge of 14,000 and $10,000 \mathrm{~km}^{3}$ year-1 resulted in an acceleration of sea-level rise to $22 \mathrm{~mm}$ $\mathrm{yr}^{-1}$. Associated with the catastrophic collapse of the Laurentide icesheet over Hudson's Bay about 8000 years ago, a similar discharge of meltwater led to rates of sea-level rise between 34 and $46 \mathrm{~mm}^{\text {year }}{ }^{-1}$.

The high apparent discharge rates together with the associated rapid rates of sealevel rise may have been effected over very short-time periods measured in weeks and years. Shaw (1989) has calculated that the catastrophic discharge of meltwater from Livingstone Lake in Canada liberated $84,000 \mathrm{~km}^{3}$ about 8000 years ago which resulted in a global rise of sea-lvel of $23 \mathrm{~cm}$ in a few weeks. The consequence was that shorelines retreated very rapidly: in Germany, the rate of retreat was $160 \mathrm{~m}^{\text {year }}{ }^{-1}$.

The margins of the Pacific Ocean are seismically active, and earthquakes trigger submarine landslides, which, in turn, generate tsunamis - seismic waves of large amplitude and long period that impact on coasts around the Pacific. Recently, the geological record from coastal lowlands in East Scotland has demonstrated the impact of a seismic wave there about 7000 years ago, associated with a submarine landslide off the Norwegian coast. Documentary records indicate similar seismic events in the North Sea and English Channel in AD 1133, 1247, 1382, 1449, 1580, 1692, 1755 and 1938. Of these the Lisbon earthquake of 1 November 1755 generated a seismic wave $13 \mathrm{~m}$ high that inundated Lisbon, and secondary waves 2-3 m high impacted on the coasts of the English Channel.

These natural rates of sea-level and coastline change and extreme sea-level events are several orders greater than anything recorded during the past 100 years, which may be an atypical period both for climatic variability and for sea-level and coastline changes, and hence an unreliable standard period for prediction. The conclusion is that coastlines are unstable, spatially and temporally; they are dynamic features that advance and retreat as the volume of water in the ocean basins changes during a glacial-interglacial cycle. 


\section{Land-level changes during the recent geological past}

The altitude at which the sea-level intersects the land is also determined by vertical land movements, and depending upon the position on a landmass that is rising or falling the sea level can appear to be falling or rising at rates greater or smaller than the global sea level rise or fall.

Land movements are occurring on very long time periods of hundreds of millions of years and are associated with the drifting of the earth's plates and subsidence in sedimentary basins. On shorter time scales of tens of thousands of years, glacial/interglacial cycles affect land altitudes.

During glaciations in Canada, Northern Britain and Fenno-Scandinavia, the crust was loaded with ice $1-3 \mathrm{~km}$ thick. The weight of ice depressed the crust by up to $1 \mathrm{~km}$. Beyond the limits of glaciation, material displaced by the ice welled up and the land rose. As the ice melted during deglaciation, the land rose in the area of glaciation, whereas in the area of uplift beyond the ice limits, the land fell. The maximum amount of uplift has been about $800 \mathrm{~m}$ in Fenno-Scandinavia, and a further $200 \mathrm{~m}$ of uplift are likely before an equilibrium state is reached.

In Scotland, southern Norway and northern Denmark, uplift following deglaciation has been calculated between 1.4 and $1.9 \mathrm{~m} / 100$ years (Shennan 1987). Compensatory subsidence around the southern North Sea ranges from 0.7 to $1.6 \mathrm{~m} / 1000$ years. In the United Kingdom, present rates of uplift and subsidence range from $<2.0 \mathrm{~mm} \mathrm{yr}^{-1}$ uplift in

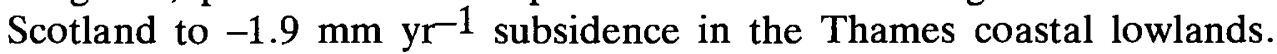

Around the south shore of the North Sea, including south-east Britain, subsidence cannot be explained exclusively by deglaciation Fenno-Scandinavia and northern Britain, but also by subsidence with the great oil-bearing sedimentary basins of the North Sea. In Germany, $5 \%$ of the $100 \mathrm{~m}$ sea-level rise during this interglacial is attributed to this latter cause.

Another cause of subsidence in coastal lowlands is the application of a sediment load, which rather like an ice load bears down on the crust, causing depression. All the great deltas in the Mediterranean display this effect. In the Nile delta, rates of subsidence range from 1.2 to $4.8 \mathrm{~mm} \mathrm{yr}^{-1}$. In the Po delta between 1900 and 1950 the rate of subsidence was $0.5 \mathrm{~mm} \mathrm{yr}^{-1}$ (Tooley \& Jelgersma 1992).

Rates of land uplift and subsidence need to be considered when calculating relative sea-level changes, and assessing the likely impacts of such changes on coastline and coastal lowlands.

\section{Forecasting floodrisks}

In the 1980's considerable interest was directed towards predicting climatic and sealevel changes, associated with the enhanced greenhouse effect, and based on a consideration of changes during the past 100 years (Figure 1). 
Figure 1
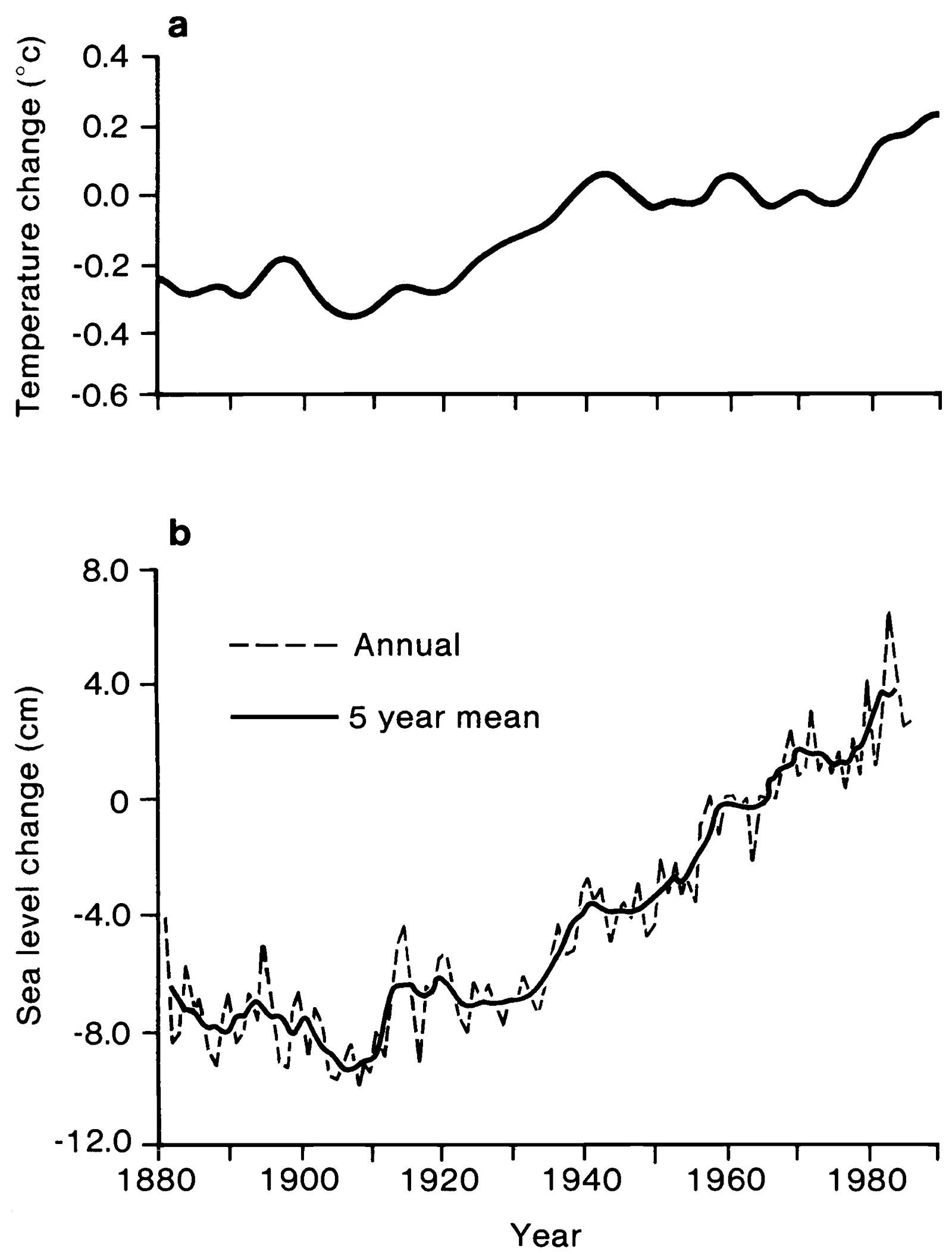
At the Villach conference (Bolin et al. 1986), it was posited that a doubling of $\mathrm{CO}_{2}$ from pre-industrial levels would occur as early as AD 2030, and this would lead to an increase in global mean equilibrium surface temperature of between $1.5^{\circ} \mathrm{C}$ and $4.5^{\circ} \mathrm{C}$. By 1990, the Intergovernmental Panel on Climate Change (Houghton et al. 1990) estimated that by $\mathrm{AD} 2030$ global mean temperature will rise $1.1^{\circ} \mathrm{C}$ above 1990 temperatures and by $\mathrm{AD} 2090$ will reach $3.3^{\circ} \mathrm{C}$ as $\mathrm{CO}_{2}$ rises above its present day level of $353 \mathrm{ppmv}$ and other greenhouse gases increase by 0.2 to $0.5 \%$ per year.

Similarly, there are many estimates of sea-level rise. Hoffman (1984) estimated that the range of sea-level rise scenarios by $A D 2075$ would be $38 \mathrm{~cm}$ to $212 \mathrm{~cm}$. This was revised down to 36 to $191 \mathrm{~cm}$ (National Research Council 1987). Wigley and Raper (1990) estimated 19 to $35 \mathrm{~cm}$ by AD 2030 whereas the IPCC "Business-as-Usual" Scenario for AD 2030 was 8 to $29 \mathrm{~cm}$ (Warrick and Oerlemans 1990). It is worth noting the rates of sea-level rise for some of these scenarios: for Hoffman's (1984) conservative estimate between AD 2000 and 2100 rates increase from 3.0 to $4.8 \mathrm{~mm} \mathrm{yr}^{-1}$, whereas for the IPCC "Business-as-Usual" best estimates from AD 2030 to AD 2100 the rates increase from 4.5 to $6.0 \mathrm{~mm} \mathrm{yr}^{-1}$. Suffice it to say, none of these rates approach in magnitude the rapid rates of sea-level rise $\left(>20 \mathrm{~mm} \mathrm{yr}^{-1}\right.$ recorded during the last interglacial and $12.000,9000$ and 8000 years ago during this interglacial, and a potential for rapid sea-level rise resides in the catastrophic discharge of meltwater from the West Antarctic Ice Sheet - the last remaining marine ice sheet on Earth containing sufficient ice to raise sea-level, if melted, by 6 metres.

Only modest increases in sea-level will have a profound effect on the incidence of damaging storm surges. Rossiter (1962) showed for the British coasts that a rise of mean sea level as little as $15 \mathrm{~cm}$ would double the probability of storm surges exceeding danger level on the east coast of England and treble the probability on the west coast. Furthermore, recent analyses, based on the record of storm surges after the 1953 storm surge event, have shown that a $20 \mathrm{~cm}$ rise alone would increase the number of storm surges equalling or exceeding the danger levels specified by the Storm Tide Warning Service from 112 to 334 for the period 1972 to 1989.

Recurrence interval calculations have not been an entirely satisfactory basis for forecasting because records of both extreme water levels and wave heights are too short. For example, the 1953 storm surge event was calculated as the 1 in 200 years event, and yet the extreme water levels of 1953 have been equalled or exceeded on at least 11 occasions in the past 38 years.

What are required are inventories of extreme water levels drawn from documentary sources and natural sources (the stratigraphic record) for each coastal lowland. From these inventories, a severity index could be calculated, and frequency patterns established: these would then serve as a sound basis for forecasting.

\section{Conclusions}

1. Rates of relative sea-level change during the recent geological past ranged from 20 to $46 \mathrm{~mm} /$ year when there was catastrophic discharge of meltwater from beneath high and mid-latitude ice sheets. This compares with a rate of rise of sea-level during the past 100 years of $1-2 \mathrm{~mm} /$ year, based on analyses of tide gauge data. 
2. Although there was greater regional variability in relative sea-level change, because of land uplift and subsidence, one impact was the landward advance of the world's coastlines by up to 160 metres/year, and extensive flooding of coastal lowlands by the sea.

3. Coastal lowlands of the world are at risk today from extreme sea water levels, and the risk has increased due to the activities of man. Areas that were once wastelands have been reclaimed, settled and developed for agricultural, residential and industrial purposes and for strategic industries such as electricity generation. Ground altitudes have declined as a result of drainage, enlarging the areas at risk from extreme water levels.

4. The increase of $\mathrm{CO}_{2}$ and other radiatively active gases in the atmosphere will have an impact on sea-levels through an increase in air temperatures and in surface water masses in middle and high latitudes. This will lead to a rise in sea-level. There may be an increase in the incidence of storms in low and middle latitudes, leading to a greater number of storm surges.

5. The $\mathrm{CO}_{2}$ content of the atmosphere today is greater than the warmest period of the last interglacial, when the sea-level was between 2 and $10 \mathrm{~m}$ higher than it is at present.

6. In England and Wales alone, 720,000 ha of agricultural land lie below $+5 \mathrm{~m}$ Ordnance Datum and this area has been affected by long period inundation on many occasions. The coastline of the U.K. is $>4000 \mathrm{~km}$ long, of which $1800 \mathrm{~km}$ are coastal protection defences with an asset value of $£$ 4-6 billion, and protect the coastal lowlands of the U.K. from periodic and aperiodic flooding.

7. We can no longer be confident, as we might perhaps have been in 1990 , that individual politicians will have any long term or lasting effect on natural processes such as sea-level rise. 


\section{REFERENCES}

BIRD, E. C. F. 1985, The study of coastline changes. Zeitsch. für Geomorph. Suppl. Bd. 57, 1-9.

BOLIN, B., DOOS, B., JAGER, J. \& WARRICK, R. A. (eds). 1986, The Greenhouse Effect, Climatic Change and Ecosystems. Scope 29. Chichester, John Wiley \& Sons.

HOFFMAN, J. S. 1984, Estimates of future sea-level rise. In, Barth, M.C. \& Titus, J. G. (eds). Greenhouse effect and sea-level rise: a challenge for this generation. New York, van Nostrand Reinhold Co., 79-103.

HOUGHTON, J.T., JENKINS, G. J. \& EPHRAUMS, J.J. (eds.) 1990. Climate change: the I.P.C.C. Scientific Assessment. Cambridge, Cambridge University Press.

National Research Council (U.S.), Committee on Engineering Implications of changes in relative mean sea-level, 1987, Responding to changes in sea-level: engineering implications. Washington, D. C., National Academy Press.

ROBINSON, G. W. \& STONE, M. J. 1990, Beach recharge. Proc. Instn. Civ. Engrs, 88(1), 1127-1130.

ROSSITER, J. R. 1962, Long term variations in sea level, in Hill, N. M. (ed.) The Sea. I. London, Interscience 590-610.

SHAW, J. 1989, Drumlins, Subglacial meltwater floods, and ocean responses, Geology, 17, 853-856.

SHENNAN, I. 1987, Holocene sea-level changes in the North Sea region. In, Tooley, M. J. \& Shennan, I. (eds.) Sea-level Changes, Oxford, Basil Blackwell, 109-151.

SPALDING, J. V. 1954, A general survey of the damage done and action taken. In, Conference on The North Sea Floods of 31 January/1 February, 1953. 16-17 December 1953. London, The Institution of Civil Engineers, 5-13.

TOOLEY, M. J. 1978, Sea-level Changes, Oxford, Basil Blackwell.

TOOLEY, M. J. 1979, Sea-level changes during the Flandrion Stage and the implications for coastal development. In, Suguio, K. Fairchild, T. R. Martin, L. \& Flexor, J.-M. (eds.) Proceedings of the 1978 International Symposium on Coastal Evolution in the Quaternary. Sao Paola, Universidade de Sao Paolo, 502-533.

TOOLEY, M.J. \& JELGERSMA, S. 1992, Impact of sea-level changes on European coastal lowlands. Oxford, Basil Blackwell.

UNEP (United Nations Environment Programme) 1990. The State of the Marine Environment. Nairobi, UNEP Regional Seas Reports and Studies No. 115. Paris, Gesnamp Reports and Studies No. 39.

VARLEY, J. (ed.) 1991, World Nuclear Industry Handbook. Sutton, Nuclear Engineering International.

WARRICK, R. A. \& OERLEMANS, J. 1990. Sea-level rise. In, Houghton, J.T. et al. op. cit., 257-281. 